\title{
Aile Baskısı nedeniyle durdurulan transplantasyon olgusunun etik analizi
}

\section{Ethical analysis of the case study which the transplantation is terminated due to parental pressure}

\section{Müesser ÖZCAN, Hatice Demir KÜRECi, Nermin ERSOY}

Muğla Sıtkı Koçman Üniversitesi Tıp Fakültesi tıp Tarihi ve Etik Anabilim Dalı, Muğla. Muğla Sıtkı Koçman Üniversitesi Tıp Fakültesi tıp Tarihi ve Etik Anabilim Dalı, Muğla. Kocaeli Üniversitesi Tıp Fakültesi tıp Tarihi ve Etik Anabilim Dalı, Kocaeli.

\section{ÖZET}

Ülkemizde organ nakline gereksinim duyan hasta sayısının her geçen gün artması, buna karşın kadavra bağışının oldukça az olması, nakillerinin çoğunlukla canlı vericilerden gerçekleşmesine neden olmaktadır. Canlı vericiden yapılan nakil sürecinde doktor, alıcı, verici ve diğer kişiler arasında yaşanabilen sorunlar, ciddi etik ikilemlerin ortaya çıkmasına neden olabilmektedir. Bu nedenle biz, ülkemizde yazılı ve görsel medyaya yansımış olan "hasta çocuğa babasından karaciğer nakli yapılması sırasında vericinin aile üyeleriyle hastanede yaşanan tartışmaların ameliyatın iptal edilmesine, dolayısıyla çocuğun ölmesine yol açıldığı" iddialarını içeren olguyu klinik etik karar verme süreci doğrultusunda analiz ettik. Olası etik sorunun fark edilebilmesine, tanımlanabilmesine ve çözüm üretilebilmesine olanak sağlayabilen klinik etik karar verme süreçlerinde; olgunun tıbbi endikasyonlarının, hastanın/vekilin tercihlerinin, hastanın yaşam kalitesinin ve olgunun çevresel özelliklerinin gözetilmesinin önemine dikkat çekmeyi amaçladık.

Anahtar Kelimeler: Klinik etik, Karar verme, Karaciğer transplantasyonu

\section{ABSTRACT}

The number of people that need an organ transplant in Turkey is increasing every day, however the organ donations are mostly from living donors as the number of cadaver donations are pretty low. Possible problems between the doctor, donor, recipient and other parties, which can occur during the transplantation process with a living donor, can cause serious ethical dilemmas. Therefore, in accordance with clinical ethical decision making process, we analyzed the case that appeared on written and visual media, including allegations of "the discussions between the hospital and recipient's family members during the liver transplantation from the father to his sick child caused termination of the operation leading to the death of the child". We aimed to draw attention to the importance of considering the medical indications of the case, patient/surrogate preference, patient's life quality and contextual features of the case during the clinical ethical decision making processes, which can enable the possible ethical problem to be distinguished, recognized and solved.

Key words: Clinical ethics, Decision making, Liver transplantation
Corresponding Author: Müesser Özcan

Adress: Muğla Sıtkı Koçman Üniversitesi Tıp Fakültesi tıp Tarihi ve Etik Anabilim Dalı, Muğla.

E-mail: muesserozcan@mu.edu.tr
Başvuru Tarihi/Received: 21-03-2016 Kabul Tarihi/Accepted: 05-04-2016 


\section{INTRODUCTION}

In Turkey, where cadaver donations are few, most of the donations are made by living donors(1).If the patient is a child - as in our case -, mother/father is chosen as a living donor in the first stage; in the presence of problems, relatives up to fourth-degree can legally be considered(2). Beyond doubt, losing a child is one of the most painful experiences for a parent in every culture. In our culture, where childcentered family approach is common, in case of a terminal illness parents can show altruistic behaviors and volunteer to be a living donor in order to save their child's life. In this study, "the case of child patient's liver transplantation", which appeared on written and visual media and is considered as ethically problematic, is evaluated by using the four box method for clinical ethical decision making process, which was developed by Jonsen et al(3). Through this ethical analysis, we intended to draw attention to the ethical aspects of ever growing organ transplantations.

Case Report: Five-year-old N.E. thinks brown colored explosives, which was bought and cut into little pieces by her sibling, are chocolate and eats them. After a while, she starts to vomit. Realizing the firework crackers coming out of their daughter's mouth, parents take their daughter to hospital. Child's clinical condition, which looks good for the first four days, gets bad after the sixth day. Doctors explain to the family that the child needs liver transplantation immediately. After the parents volunteer and it appears that the father's liver is a match for the transplantation. Chief Doctor starts operation preparations with the team. Doctors explain to the family that they will first open the abdominal area of the father, afterwards if a situation occurs -even though the chances are one-percent- that interferes with the transplantation, they will operate on the mother, who also volunteered. . The father gives his informed consent after being informed about the operation. Both parents sign the necessary informed consent form for the transplantation process of the child.

On the operation day, the father and the child are taken into the operating room and mother is prepared for operation just in case of any possible problems. While the father's abdominal area is opened, a disorder occurs in front of the operating room door. Father's parents demand that the operation to be terminated and no piece of liver should be removed for the transplantation. While the father (donor) is lying with his abdominal area open in the operating room, the doctor, who is informed about the disorder, goes outside and tries to convince the parents for the operation for almost an hour. However, family elders object to the doctor by saying that the child will not make it anyway and their son might become disabled if they remove a piece from his liver. After these objections, doctors close the abdominal area without removing the necessary piece, on the grounds that the decision is inconsistent. Surgical team terminates the operation due to the inconsistent behaviors, until the situation becomes clear. However, a cadaveric donation cannot be found in the necessary timeframe and the child dies after two days $(4,5)$.

\section{ETHICAL DECISION MAKING PROCESS}

As it can be seen from the model (Table 1) developed by Jonsen et al., which was developed in order to make the solution of the medical and ethical problems encountered by clinicians easier, is considered/evaluated under four main topics; medical indication, life quality, patient preferences and contextual features. During the ethical decision making process, medical facts like patient's clinical situation, diagnosis and treatment are reviewed, meanwhile the suggested approach and its aims should be determined. Regulating, sustaining and improving the life quality is one of the main goals of medicine. Therefore, life quality is a building block for ethical decision making process. In all medical treatments showing regard to a patient's preferences based on their own evaluation of profits and burdens depending on their own values, has an ethical importance. Medical indications, life quality and patient preferences reveal the basic features of the case. But every 
Table 1. Clinical ethical decision making process.

MEDICAL INDICATIONS

(The Principles of Beneficence and Nonmaleficence)

- What is the patient's medical problem? (history, diagnosis, prognosis)

- Is the problem acute? Chronical? Critical? Emergent? Reversible?

- Is the treatment effective? Palliative? Burdensome?

- What are the goals of treatment (goals of medicine)?

- What are the probabilities of success?

- What are the plans in case of therapeutic failure?

\section{QUALITY OF LIFE}

(The Principles of Beneficence, Nonmaleficence, and Respect for Autonomy)

- What are the prospects, with or without treatment, for a return to a normal life?

- What physical, mental, and social deficits is the patient likely to experience if treatment succeeds?

- Are there biases that might prejudice the provider's evaluation of the patient's quality of life?

- Is the patient's present or future life quality unbearable?

- Are there plans for palliative care?
- Is there any plan or rationale to forgo treatment?

\section{PATIENT PREFERENCES}

(The Principle of Respect for Autonomy)

- Is the patient mentally capable/legally competent? Is there any doubt of incapacity?

- If competent, what are patient's treatment preferences?

- Has the patient been informed of benefits and risks, understood this information, and given consent?

- If incapacitated, who is the appropriate surrogate? Is the surrogate using appropriate standards for decision making?

- Has the patient expressed prior preferences?

- Is the patient unwilling or unable to cooperate with medical treatment? If so, why?

\section{CONTEXTUAL FEATURES}

(The Principles of Justice and Fairness)

- Are there family issues that might influence treatment decisions?

- Are there provider issues that might influence treatment decisions?

- Are there economic factors?

- Are there religious and cultural factors?

- Are there limits on confidentiality?

- Are there problems of allocation of resources?

- How does the law affect treatment decisions?

- Is clinical research or teaching involved?

- Is there any conflict of interest on the part of the providers or the institution?

medical indication is a part of a wider context including people, institutions, and material and social regulations. Care of the patient is affected - positively or negatively - by the possibilities and limitations of this context. Therefore, both the patient and his or her proxies can be affected by these contextual features. Especially if these decisions have emotional, psychological, financial, legal, scientific, educational, religious effects on others, it might be inevitable not to be influenced. Thus, in every case contextual features should be determined and examined. These contextual features are extremely significant for the comprehension and solution of the case (3).

\section{ETHICAL EVALUATION}

In this case many ethical subjects like respect for autonomy, full and valid informed consent, parental consent, nonmaleficence, high beneficence of the child, portioning of the limited resources and altruism are mentioned. In the light of the information in the first box (medical indications), patient's medical problem is urgent, treatment (transplantation) is burdensome and even if it requires a limited resource, it might increase child's chances of survival and life quality. Mortality rate for the donor father is very low and the most important risk is liver failure. However, this risk is decreasing, since the need for graft is small. Unless an additional complication related to the operation occurs, the father will be discharged from the hospital after one week and can sustain a normal life (Table 2).

Second stage of the decision making process is the evaluation of the preferences of the patient and/or surrogates, relatives. For incapacitated patients and especially for small children parent's altruism and acquiring a valid informed consent becomes crucial. In our case, since the patient is five years old, the decision about transplantation was made by the parents. Therefore, the parents were informed about the necessary organ transplantation procedure and the fact that the organ can be donated either by a living or a cadaveric donor. Since the problem was urgent, both parents have volunteered as donors (Table 2). Parents decided that the father 
Table 2: Adaptation of the case to the clinical ethical decision making process.

MEDICAL INDICATIONS

(The Principles of Beneficence and Nonmaleficence)

- Child's medical problem is urgent,

- Treatment is burdensome,

- Resources are limited (organ transplantation)

- There is no other way of survival except organ transplantation,

- Survival is possible if organ transplantation is performed,

- Tissues of the father and the mother are compatible with the child,

- Risks for the father regarding the operation are low and he should be observed as an inpatient approximately for a week.

QUALITY OF LIFE

(The Principles of Beneficence, Nonmaleficence, and Respect for Autonomy)

- Life quality of the child is poor in the current situation,

- Without the organ transplantation life quality of the child will get worse and chances for survival might disappear,

- An increase in the life quality is possible through organ transplantation.
PATIENT PREFERENCES

(The Principle of Respect for Autonomy)

- Since the recipient is a child (five years old) parental informed consent is absolute,

- Parents (who give surrogate informed consent naturally) want their child to have a liver transplantation,

- Parents decided to be donors for their child,

- They decided that first the father will be operated for the transplantation and in case of a setback mother will be the donor and they informed the doctors about their preferences.

CONTEXTUAL FEATURES

(The Principles of Justice and Fairness)

- In Turkey adults can be living or cadaveric donors on the condition that they provide voluntary consent.

- Grandparents of the child do not want their son to be a living donor and intervene in the situation.

- There are no legal or societal regulations concerning the approval of the family of the adult living donors for the consent of the donor should be evaluated first for the transplantation. Even though they volunteered, it is possible that the sudden illness of their child and the possible emotional mood shifts about donating their own organs in order to save the child might affect their comprehension, decision making process and consequently their voluntariness. There is a high possibility for a parent, whose child is hovering between life and death will make sacrifices. Altruism after all is acting upon someone else's interests rather than self-interest. Although it is desired that the altruism, which is an important concept for organ transplantation, showed by the living donor to be a conscious altruism; it is crucial to have an informed consent process in order to protect the donor $(6,7)$. It cannot be known if the parent's altruism in our case affected their autonomous choices or not, but attention was paid for them to be informed thoroughly about being a living donor, to comprehend the provided information and to give informed consent voluntarily and without any pressure. Not being able to provide enough time for the people to think during informed decision making process can affect the process negatively. Particularly their voluntariness might be affected since the urgent status of the situation prevented them to take enough time to think about themselves.

When the situation is evaluated in terms of life quality, clinical picture of the child is bad (Table 2 ). The balance between the consequential benefits, burdens and risks through the transplantation for both the recipient and the donor should be taken into consideration. When the benefits acquired outweigh the burdens for both parties, decision can be ethically advocated. The biggest benefit for the child is undoubtedly survival. There are no physical benefits for the father; on the contrary there might be some risks. However, it is important to state some important benefits; the father will regain his life quality in a short time and his self-respect as a result of saving the child's life will increase. Therefore, by suggested organ transplant it is possible to increase the life quality of the recipient and for the donor to regain his own life quality in a short period of time.

The recipient and donor should be pscyhosocially evaluated in regard to the contextual features box such as culture, belief, point of view, finance and laws. Behavior of the spouse and family should be investigated and if there is any disagreement it should be solved before 
the operation (8). In our case, the mother has also volunteered (Table 2). However, the father's autonomous decision about the surgery was disregarded by his relatives and the necessary organ could not be removed. If the donor is married, the doctors are responsible to investigate whether or not the spouse is aware of this decision for organ or tissue donation and to ascertain it in writing according to the 7. Article of the Law number 2238 about Organ and Tissue Procurement, Preservation, Grafting and Transplantation (2).This law is important, since not only the donor but also the spouse of the donor is affected by the tissue or organ donation. However, this doesn't mean that the donation will be terminated if the informed and volunteered spouse objects (9).The same law doesn't hold the doctors responsible to inform or ascertain an approval from the parents or the siblings of the adult donor. In addition to that, according to the 3 . Article of the Convention on the Rights of the Child, the best interest of the child should be taken as basis in all child-related issues (10). Thus, the fact that the organ donation could not be carried out based on the pressure from donor's family members like parents or siblings; does not correspond to father's autonomous decision, doctor's authorization, parental consent, goals of medicine and the Convention on the Rights of the Child, which emphasizes the necessity to act upon the best interests of the child in any circumstances.

\section{CONCLUSION}

In medical practice almost all of the treatment process is directed towards the patient's body. On the other hand, during organ transplantations with living donor's the physical integration of another individual besides the patient can be disrupted. Thus, complicated relations and problems might occur between the doctor, recipient, donor and other parties during organ transplantations. As in our case, false information embedded in the local culture about the possible risks for the healthy donor might take away the survival chance of a child.

In this case, the surgeon had to comply with the objections of the donor's family, even though he was autonomously authorized by the patient for the surgery. Yet what was expected from the surgeon was to act according to the donor's informed consent and not to terminate the surgery unless the donor retrieves his consent or a medical necessity occurs. The recessiveness of the surgeon, put the recipient's life in danger and caused unnecessary surgical intervention for the donor. Therefore, during the ethical decision making process it is important for the surgeon to weigh the best interests of the child and the possible dangers for the donor with an informed consent based on the principle of proportionality.

In conclusion, it can be said that father's autonomous decision, child's best interests and even Principle of Nonmaleficence, which survived since Hippocrates until this day, were ignored.

Awareness about organ transplantation should be raised; the doctors should be provided a suitable environment to practice clinical ethical decision making process in case of an ethical dilemma, to produce solutions and to seek ethical consultation with hard decisions. To this end, it would be beneficial to start ethical trainings for the clinicians and to discuss defensive medicine leading unethical practices in various platforms.

\section{REFERENCES}

1. Moray G, Arslan G,Haberal M. The history of liver transplantation in Turkey. Experimental and clinical transplantation: official journal of the Middle East Society for Organ Transplantation 2014;12: 20-23.
2. Organ veDokuAlinmasi, SaklanmasiveNakliHakkindaKanun (The Law about Organ and Tissue Procurement, Preservation, Grafting and Transplantation), ResmiGazete, Turkish Law, no. 2238, 29 May 1979. 
3. Jonsen AR, Siegler M, Winslade WJ. Clinicalethics: a practicalapproachtoethicaldecisions in clinicalmedicine.6th edition. New York,McGrawHill, 2006.

4. http://arsiv.sabah.com.tr/2008/10/20/haber,62F3 D74BBB5245A9AFF6A1EC676DE8E5.html.(Access date:02/12/2015).

5. http://www.radikal.com.tr/radikal.aspx?atype=habe ryazdir\&articleid=904393. (Access date:02/12/2015).

6. Wright L, Ross K, Abbey S, Levy\& D. Grant G.Livinganonymousliverdonation: casereportandethicaljustification. Americanjournal of transplantation 2007; 7(4):1032-1035.
7. Turk Tabipleri Birligi Etik Bildirgeler CalıstayiSonuc Raporu (TurkishMedicalAssociationEthicalGuidelines). Ankara.Turk Tabipleri Birligi Yayınlari,2008.

8. Olbrisch ME, BenedictSM, HallerDL, Levenson JL. Psychosocialassessment of living organ donors: clinicalandethicalconsiderations.progtransplant 2001;11(1):4049.

9. Elcioglu OS.Organ aktarımıveetik (Organ transplantation and ethics.). In Cagdas Tip Etigi (Contemporary Medical Ethics.).Erdemir AD, Oncel O, Aksoy S (eds). 1 thedition. Nobel Tıp Kitapevi, 2003:309-324.

10. CocukHaklariSozleşmesi (The Convention on the Rights of the Child), Resmi Gazete, Turkish Law, no.22138, 9 December 1994. 